\title{
The Reformation of Scholarship: A Reply to Debora Shuger
}

\section{Citation}

Simpson, J. 2012. The Reformation of Scholarship: A Reply to Debora Shuger. Journal of Medieval and Early Modern Studies 42(2): 249-268.

\section{Published Version}

doi:10.1215/10829636-1571876

\section{Permanent link}

http://nrs.harvard.edu/urn-3:HUL.InstRepos:14807877

\section{Terms of Use}

This article was downloaded from Harvard University's DASH repository, and is made available under the terms and conditions applicable to Open Access Policy Articles, as set forth at http:// nrs.harvard.edu/urn-3:HUL.InstRepos:dash.current.terms-of-use\#OAP

\section{Share Your Story}

The Harvard community has made this article openly available.

Please share how this access benefits you. Submit a story.

Accessibility 
The Reformation of Scholarship: A Reply to Debora Shuger

James Simpson

Harvard University

In 2008 Debora Shuger published an essay, "The Reformation of Penance," in which she took aim at revisionist Reformation scholarship." By "revisionist Reformation scholarship," Shuger means a relatively small slice of the vast scholarship on the Reformation. ${ }^{2}$ She takes aim at that scholarship on the Reformation in Britain, produced in the last twenty or so years, which dissents from the Whig, Protestant-triumphalist account. To put the matter crudely, this revisionist scholarship presents the English Reformation as more top-down than bottom up. ${ }^{3}$

In fact her target is even more restricted than this revisionist historical scholarship. Shuger does not make this crucial distinction, but there is in fact a sharp difference between revisionist historical scholarship on the one hand, and, on the other, a revisionist literary historical movement in English literary studies, also now about twenty years old. ${ }^{4}$ The interests and commitments of the literary historians were and remain significantly different from, even largely opposed to, those of the revisionist historians. While the religious historians 
restrict themselves to religion and write from within unmistakable confessional traditions, literary historians focus instead on the key term "periodization," whose significance extended across all discursive practice, religious and secular. ${ }^{5}$ While the religious historians are committed to a later medieval period characterized by wholly coherent, largely consensual cultural practice, the literary historians perceive a later medieval period characterized by contest and dynamic cultural dissonance. The confessional historians are determined to dig the medieval/Early Modern periodic boundaries even deeper; the literary historians seek, on the contrary, to test out the force of an alternative periodization altogether. That alternative might extend coherently from, say, Lollardy to the Civil War.

Ignoring these distinctions, Shuger took aim in particular at "revisionist" treatment of the sacrament of penance. She used my Reform and Cultural Revolution, published in 2002, as exemplary of the error of the revisionists with regard to penance. ${ }^{6}$ Her larger charge against the revisionists is that they tend to offer a history of Loss, and that they have introduced "polemical distortion" into Reformation scholarship that had been free of that for fifty or so years. Her specific charges against 
my book are that I mischaracterize post-Reformation theology of penance in two respects: the value of works in penitence; and the function of satisfaction. By way of correction, Shuger offers her own account of Protestant soteriology, and makes comparison with contemporary legal practice.

In my view, Shuger does the following in her essay: she mischaracterizes pre-Reformation theology of penance; and she deeply underestimates the seriousness with which Reformation soteriological theology undoes its principal pre-Reformation counterpart. Before I turn to those more specific arguments of intellectual history, I am bound to step back from the heat of controversy and remark both on my admiration for Debora Shuger's scholarship in general, and on my lack of admiration for her scholarly procedure in this particular essay. My focus on the fragility of her scholarly procedure is, of course, in part polemical, but in part also designed to establish basic ground rules of engagement in this territory. That such an accomplished scholar should herself make such elementary errors of method in this debate is so striking as to deserve pause and comment. My brief response, then, comes under two heads: (i) methodology; and (ii) intellectual history. My aim across both is less self-defense (though of course I 
also intend to achieve that) and more reflection on "polemical distortion."

My account of pre-Reformation theology is erroneous, according to Shuger. Let us, she suggests, take a good look at how "late medieval Catholic theology envisaged the process of meriting salvation through penitential works." Her test case is William Allen's Defense...[of] Purgatory, published in 1565," "which summarizes the late medieval doctrine of penance." ${ }^{8}$ This work, we are assured, is of particular value, because "Allen was not some village priest, whose theology might be thought eccentric or subChristian, but an Oxford man and future cardinal."9

Before we proceed any further, let us pause to consider whether or not William Allen is fairly described as typical of "late medieval Catholic theology." Allen was indeed educated at Oxford; he graduated in 1550. Between 1556 and 1558 he "he must have been actively involved in the Marian purge of the university" $i^{10}$ with the accession of Elizabeth he stayed in Oxford until 1560, before finally leaving England never to return in May 1565. That same month he published the text that shuger takes as typical of 
late medieval "Catholic" theology, precisely because it was written by a future cardinal, and not some "village priest." We need not pursue the rest of Allen's career as a leading English recusant; as founder of the English College at Douai; as promoter of the Catholic missionary effort in England, however intense the danger faced by missionaries; as very willing recipient of the support of the spanish monarchy; as promoter of Jesuit spirituality; as ardent papalist for whom the excommunication of Queen Elizabeth was central to his program; as active planner of invasions of England; and as protester against the torture of Catholics. ${ }^{11}$

We need not pursue that later career, but we do need to say that, on the face of it, someone less typical of late medieval theologians would be hard to imagine, precisely because Allen was a cardinal, and precisely because his entire polemical life was conducted in exile, in conditions and environments of a kind unknown to any pre-Reformation English priest.

Shuger, perhaps, might at this point object (weakly) that Allen's biography is beside the point; we will need instead to consider the theology, not the theologian, for the claim that Allen's work is of "particular value" for its summary of the late medieval doctrine of penance. ${ }^{12}$ I 
turn, accordingly, to Shuger's exhibit A, William Allen's Defense...[of] Purgatory. This was published in 1565, just two years after the final session of the Council of Trent. It is very long (just under 600 pages), and not in fact about the sacrament of penance at all. The text is instead a defense, simultaneously cumbrous and ferocious, of the existence of purgatory, as its title declares. The cumbrousness derives from its extensive citation of Biblical and patristic support texts, while the ferocity derives from its account of the inadequacy of the sacrament of penance.

Allen confronted powerful and derisive evangelical dismissal of the existence of purgatory. That dismissal was already of at least forty years standing in England by the time Allen wrote in $1565 .{ }^{13}$ Faced with that tradition, Allen defensively insists on the both the fact and the ferocity of purgatorial pain as compensating for the insufficiency of penance. Such penitential pain as cannot be discharged in this life must be discharged in the afterlife; so it is that even the righteous must cry for forgiveness after death,

crying without ceasing forgive us our debtes: Quia non iustificabitur in conspectu tuo omnis vivens. For no man alive shall be able to stand before the face of 
God in his own justice or righteousness, and if these light sins should never be imputed, then it were needless to cry for mercy, or confess debt, as every man doth, be he never so passing holy. ${ }^{14}$

This passage is clearly written by someone who has been reading, and wishes to answer, evangelical soteriology. The buzz words "righteousness" and "imputed"; the use of a citation from the penitential Psalm 142 (Vulgate) that would strike an evangelical ear and eye: these features imply a web of interlocution specific to the sixteenth century. This is, needless to say, unsurprising, given that Allen is writing in the 1560s, in the wake of what for him must have been shocking defeat; Melanchthon and Calvin are among his stated interlocutors in the text. ${ }^{15}$

In sum, my lesser, though substantial, point is this: Allen's text is not a summary of the late medieval doctrine of penance at all. The larger, historiographical point is that the text is in no way typical of late medieval theology. It is, as all texts are, one way or another, instead very much of its moment, fighting battles specific to that moment.

Shuger's case is that because Allen is a prominent sixteenth-century Catholic cardinal and theologian, he is therefore a typical representative of late medieval 
theology. I leave aside the question of who is more representative, village priest or future cardinal (or any other contender). Even as it stands, however, Shuger's assumption is, in my view, irretrievably flawed. The assumption is symptomatic of a historiography for which confessional identities are stable across time, and of a historiography for which those stable confessional identities are the cause, not the product of historical change. ${ }^{16}$ Such an assumption contravenes a basic principle of historicism -- that of historical specificity -- in so flagrant a way that the point need not, perhaps, be further belabored. True, Shuger notes in a footnote that the tract is "obviously postmedieval," but insists that its theology is that of the "standard high scholastic model."17 Even were it the case that Allen was repeating the "standard" line (which even from our tiny example we can see is not the case), the standard line repeated in new circumstances is no longer the standard line; the circumstances invest it with new meaning.

So Shuger, it seems to me, commits a serious breach of historicist protocol. She connects and identifies two very different historical moments. Her large conflation of periodic and confessional descriptions is not, however, the only such conflation in the essay under review. Shuger 
wants to go very much further. For she goes on to conflate a pre-twelfth-century penitential regime with two others: a late medieval and a Counter-Reformation regime. She thus argues that, because Allen's penitential system is focused on specific acts, it is identifiable with much more archaic systems. She has in mind the pre-inquisitional, pretwelfth-century penitential system, in which sins had specific payments, and in which penitence was primarily a form of social reconciliation. ${ }^{18}$ By Shuger's account, Allen's "persistent metaphors...rise from archaic ground." This "secular system of composition migrated from early Germanic tribal codes into the Anglo-Saxon penitentials and from thence into the Continental ones, so that by the ninth century it had become standard church practice to allow a corporeal penance...to be commuted into a monetary payment."19 Shuger wants closely to associate this system with Allen's post-Tridentine account of penance.

Shuger, then, elides very large cultural territories here. In fact she elides at least three very distinct regimes ranging from the seventh to the late sixteenth century: early medieval, pre-inquisitional penitential regimes designed primarily to achieve social reconciliation; late twelfth-century inquisitional, private penitential regimes, themselves derived form new legal 
cultures in which confession was the queen of proofs; ${ }^{20}$ and counter-Reformation penitential theory. ${ }^{21}$ All three of these systems are subsumed under the term "late medieval doctrine of penance." Of course there are connections between these regimes, but there are also significant differences. ${ }^{22}$ Elision of this vast and differentiated stretch of cultural history onto a monolithic block simply will not do.

Methodologically, then, Shuger's characterization of late medieval penitential theology stands in need of entire restructuring. What of her descriptions of intellectual history? Are they any more compelling?

Shuger's disagreement with Reform and Cultural Revolution focuses on two points (i.e. the value of works and the place of satisfaction) on which I am said to "center" my discussion. ${ }^{23}$ I readily concede that I do center my account on the differing function of works in late medieval and evangelical theology. The question of satisfaction is not, however, central to my argument at all; in fact it consists of one subordinate clause. Shuger's unhappiness with the subordinate clause concerns the question of whether satisfaction precedes or follows 
absolution. ${ }^{24}$ She insists that it follows absolution. I thank shuger for her possibly just correction of my subordinate clause, ${ }^{25}$ on which I will reflect, but for the rest of this essay I focus on the issue of works. That issue is, I agree, central to my argument, and central to our difference.

Shuger posits the following: (i) that "Tudor protestants, like medieval Catholics, repeatedly affirm that our good works and our repentances, both of which are themselves God's gifts, do have, in Simpson's words, 'a real purchase on God" ${ }^{26}$; and (ii) that the Protestant account of divine justice is not retributive. Protestant writers "consistently reject this [retributive] model"; ${ }^{27}$ "with the rejection of revenge as the end of divine justice comes a change in its object, which is no longer the act but...the person." The self, by this account, is conceived as "simultaneously embodied in and anterior to its actions" ${ }^{28} \mathrm{~A}$ "tit for tat" conception of retribution now repudiated, the "objects of divine judgment are not tats, but people."29 Shuger gives some examples of a kindly, fatherly Protestant God whose "old kindness" encourages the sinner. The sinner's heart is not at rest until he has "heard the voice of his father that all is forgiven." ${ }^{30}$ This new concept of selfhood is aligned with the jurisprudence of equity; the 
absence of a "retributive theory of punishment" in "TudorStuart jurisprudence seems remarkable indeed."31 ${ }^{31}$ Shuger aligns the jurisprudence of equity, as it looks to persons beyond acts, with the absence of a retributive, worksdirected soteriology in evangelical theology.

In sum, as distinct from an archaic, retributive, tit for tat medieval "Catholic" system that characterizes early medieval, late medieval and Counter-Reformation penitential theology, we have a Protestant penitential system that recognizes people; that is not retributive; and that is analogous with the legal practice of Chancery, which judges "ad personam, in contrast to the common law, which judges ad rem." All the examples given are examples of kindly forgiveness.

How do I respond to this especially stark, extensive and rigid periodic characterization? One simple response would be to point out that my book took the story only up to 1547. For Shuger to cite the astonishingly subtle and profound Hooker, for example, ${ }^{32}$ is entirely beside the point, since Hooker's of the Laws of Ecclesiastical Polity was published in the $1590 \mathrm{~s}$ and beyond, when the institutional situation of the English Church was entirely different. The same is true of her citations of Spenser, Donne, and Coke. My book was about that fascinating, fluid, 
pre-institutionalized, pre-confessionalized stage of postReformation culture, up to the death of Henry VIII. Shuger's slide away from the first half of the sixteenth century constitutes a further major error of method.

Then how do I respond to Shuger's intellectual history as it applies to the first half of the sixteenth century? Shuger confesses herself bewildered by Reformation revisionism. Revisionists are dismissed as merely "partisan." After all, faced with such a stark contrast of a vengeful, retributive Catholic soteriology and its equitable, kindly Protestant counterpart that considers people not tats, how could the revisionists engage in such "polemical distortion"? "Truly," comes the response at the close of Shuger's essay, "I don't understand why."

In my view Shuger's incomprehension of revisionism derives from her massive under-reading of the seriousness of the Lutheran position. Never once does Shuger mention Luther's relentless, repeated dismissal of works as a way of remitting the debt of sin; Luther's consistent and fierce denial of free will; or Luther's predestinarianism. Neither, in her account of the Lutheran emphasis on person before act, does she make mention of the Lutheran notion of simul iustus et peccator (simultaneously justified and a sinner). To be sure, Luther does focus relentlessly on the 
legal persona before the act, but that legal persona is judged always already guilty, and guilty before any act. This is not equity as shuger describes it.

I could cite passages from Luther and Tyndale to exemplify these much darker positions. Anyone, however, who knows the material will be unsurprised, and perhaps a little bored, by such a blow by blow set of citations. They can all be found in the standard sources. ${ }^{33}$

Alternatively, we could lay out the basic ingredients of the Christian theologies of justification, particularly as regards penance. If we did that, we would say that all such theologies are conscious of works at one end and grace at another. Christians can reconcile themselves with God's justice either though works, or through God's gift ("gratia"). Theologies at one end of the spectrum of possible combinations lay powerful emphasis on human free will and capacity to perform effective works that satisfy God (e.g. Pelagianism). At the other end of the spectrum, other theologies deny the possibility of free will, and assert that reconciliation is wholly a matter of God's gracious gift (e.g. Lutheranism). Between these two extremes, other theologies develop a dialectic of works and grace. These middle-ground theologies recognize that everything is ultimately dependent on divine grace, but 
posit that God will graciously allow works into the equation one way or another. Along this spectrum, we would place most late medieval positions somewhere in that middle ground, positing a dialectic of works and grace. By contrast, we would place the Lutheranism that entered England in the 1520s on the far end of the grace alone end: even more extreme than Augustine, Luther denies the freedom of the will and derides the possibility of good works. This is uncontentious and rehearses platitudes of theological history ${ }^{34}$

Rather than hammering these platitudes, let us, then, instead, attempt to capture afresh the shock of the Lutheran new by turning to a sixteenth-century source. If Shuger, happily in possession of her forgiving and equitable evangelical soteriology, is bewildered by revisionists, let us listen to a mirroring bewilderment from the sixteenth century.

In Book 8 of his Confutation of Tyndale's Answer (1532-33), ${ }^{35}$ Thomas More responds to the evangelical Robert Barnes' account of where the church is, and how she is to be known. Instead of deploying direct attack, More reverts to a much more efficient technique, the use of fiction. He imagines not a cardinal as his best representative of preReformation soteriology in the 1530s, but instead a 
merchant's wife: "let us suppose that some good honest merchant's wife...had begun to fall in some doubt and fear, lest the faith that she had before learned of the Church...were untrue and dangerous to live and die in." As he does with the young scholar in the Dialogue Concerning Heresies (1529), More carefully positions the woman as hesitating between the religion in which she grew up, and the new religion. ${ }^{36}$

The woman procures a copy of Barnes' book and reads it secretly, partly pleased, partly displeased. ${ }^{37}$ Moved to meet with Barnes, she is brought to "where none were present but such as were toward the fraternity" (More evokes the lexis of the conventicle); she promises Barnes that she will no longer believe everything the priest tells her, and asks him to declare just one thing, "which is the true Church?"38 "Barnes" directs her to read "the new testament of Tyndale's translation, and other books of his, and of his own...and therein should she find the truth."39 The woman replies that scripture is hard; besides, teachers expound it in such contradictory ways, some "for the sacraments, and some against them...some for good works, and some for faith alone, some for purgatory and some against it." So she needs a reliable teacher, "unto whose credence I may 
trust in the construction." She needs to know the preacher before she can know scripture.

More is clearly framing his narrative to suit his own interests here, by underlining the fact that scripture does not interpret itself, and requires an interpretive community of trust. ${ }^{40}$ Where, however, is the woman to find the true preacher through knowledge of whom she will know Scripture? Of course, Barnes will tell the woman that she will be moved inwardly to acknowledge the true preacher when she meets him, to which suggestion the woman is imagined to reply that "one example at one time of one man's deed...giveth us not a general rule." ${ }^{41}$ We are now so far removed from Christ, that the grounds for trusting in one man who would construe the scriptures are less secure, especially as he will disagree with many of his "own fellows."

Barnes will object at this point that the common preachers of the carnal Church make men believe that "dumb sacraments, and ceremonies, and good works, should do good to the soul," by contrast with the "new preachers of the very true Church which is spiritual." More's imagined wife becomes ever more recalcitrant, since she insists that she can only know that a preacher's doctrine is true not by his own authority, but only on account of the surety she has 
that the preacher's doctrine is the doctrine of the whole catholic Church.

Her questions about the whereabouts of the church are forceful, but less impassioned than her comments about the soteriological consequences of that invisible Church. Every saved person, Barnes is imagined saying, "shall attain the salvation by the only election of the Lord, without any part of their own devoir any thing doing thereto." ${ }^{42}$ The wife imagines the case of her neighbor and herself coming to church in order to learn the right way to heaven. Do you expect me to believe, the wife is imagined saying, that God will bring her to heaven, and "leave me still in darkness and ignorance, and let me fall into hell, for none other cause but only for he [God] list to choose her, and leave me unchosen?"43 Is she expected to believe that God would act thus, without any reason other than his not wishing to choose her? "In good faith," concludes the wife to Barnes, "I take God for so good that I can never believe you therein." 44

According to the new theology we must, says the wife, believe that we shall be damned unless we believe correctly, and that we can believe correctly only by scripture. But that scripture can be learned only by a true teacher, whose identity is impossible to know; and God will 
damn us for not understanding it correctly, regardless of our works.

The wife, in short, focuses principally in the question of the true Church's identity, whereabouts and authorization. Those issues also, however, inevitably provoke soteriological questions. Once she broaches evangelical soteriology, the wife points to what strikes her as the sheer monstrosity of a God who looks to persons without regard to acts, and a God whose choices remain utterly inscrutable.

Now of course More nor his imagined wife are not exactly typical of late medieval theology either, but the Confutation is a valuable source at this point for registering the shocked incredulity that predestinarian soteriology provoked by comparison with a subtle alternative that takes works and free will into account. Leaving More's fictional wife aside, is it unreasonable of More thus to express shock at evangelical theology in 1532? Rather than following Shuger by reverting at this point to, say, Hooker, let us turn instead to some texts available in 1532 to answer that question.

I begin with Luther's account of the relation of works to faith in his Freedom of a Christian, of 1520: ${ }^{45}$ 
This faith cannot exist in connection with works that is to say, if you at the same time claim to be justified by works, whatever their character...Therefore the moment you begin to have faith you learn that all things in you are altogether blameworthy, sinful and damnable, as the Apostle says... "There is none righteous, no not one...they are all gone out of the way, they are all made unprofitable" [Rom. 3:10-12, citing Psalm 14:1-3]. When you have learned this you will know that, if you believe in him, you may through this faith become a new man in so far as your sins are forgiven and you are justified by the merits of another, namely of Christ alone. ${ }^{46}$

This passage compresses the essence of the Lutheran system into short compass: humans share an irredeemable abjection before God; they can do nothing to escape from that abjection; only a psychological conviction, or faith, in God's promise of salvation will serve to relieve the despair of one's abject condition; the grounds of that promise of salvation have been laid by the works of God alone, in Christ. 47

Many consequences, momentous for the formation of early modernity, flow from this reaffirmation of Pauline 
spirituality. Above all, spiritual experience is relocated from action in the world, and placed instead in a psychological act of faith alone. Action in the world, invested with the dignity of labor, and performed in the hope of congruent reward, is dismissed as always already flawed and utterly inadequate. If action in the world is useless, then so too is the sacrament of penance as understood by the Catholic Church useless, since that requires works of satisfaction for sins committed. The Christian faces an angry God alone but for his faith in Christ's saving action. In this newly defined spirituality, the spiritual life is essentially an emotional life, informed as it is by the emotional content of both terror and overflowing gratitude.

Not only are works dismissed, but Scriptural injunction to do those works is also transformed from injunction to threat. For what, in the Lutheran system, is the function of read scripture? If the Bible is indeed an edifying book, the ground for that claim would presumably be the models of action provided by the book. If, however, one's theological premise is that righteous works are simply out of fallen human reach, then what purpose can be served by the Bible's promotion of good works? There is a very long history of reading in the west that defends the 
reading of books by accentuating the way in which books provide ethical models. ${ }^{48}$ When Luther places the Bible in so central a position, we might expect him to be signing up to that tradition. After all, the Bible is taken not only to furnish many models of ethical behavior, but it unquestionably prescribes ethical behavior with a certain frequency and force.

If we expect Luther to enlist himself in this tradition, we will be badly disappointed. For, on the contrary, Luther explicitly denies that the works promoted by the Bible serve any but the function of threatening readers with powerlessness, and provoking despair at that powerlessness. The very point of the prescription is to insist that the reader cannot fulfill it. For Luther, the power to change oneself, or the world, through the models provided by one's Biblical reading, is a receding horizon: the model for change only reveals one's incapacity to imitate that model. The model, that is, can only provoke despair at the reader's impuissance to base action on the model .

Luther underlines this point explicitly in The Freedom of a Christian, and he will make it more forcefully within a few years, in his fierce debate with Erasmus about 
reading, moral effort, and predestination. ${ }^{49}$ This is what he says in The Freedom of a Christian:

Should you ask how it happens that faith alone justifies and offers us such a treasure of great benefits without works in view of the fact that so many works, ceremonies, and laws are prescribed in the Scriptures, I answer: First of all, remember what has been said, namely, that faith alone, without works, justifies, frees, and saves...Here we must point out that the entire Scripture of God is divided into two parts: commandments and promises. Although the commandments teach things that are good, the things taught are not done as soon as they are taught, for the commandments show us what we ought to do, but do not give us the power to do it. They are intended to teach man to know himself, that through them he may recognize his inability to do good and may despair of his own ability. ${ }^{50}$

Lutheran reading is, by this account, a permanent experience of recession, a Tantalus-like experience of reaching out to something that is inevitably beyond one's grasp. The point of the reading is not to offer the model, but to underline that the reader is too sinful to profit from the model. The immediate point of reading (and only 
reading will save) is, that is, to provoke despair at that self anterior to works. That despair is part of the emotional dialectic of salvation.

Luther's account of soteriology fails to confirm one of Shuger's claims (if we restrict her claim to the bounds of 1547) that "Tudor Protestants...repeatedly affirm that our good works and our repentances...do have...' a real purchase on God." "51 But Luther was not, I concede, a Tudor Protestant. Tyndale, I also concede, stresses more than Luther the value of good works as a sign that God's decision has gone in the Christian's favor, ${ }^{52}$ but that is no affirmation of having purchase on God, since God is not persuaded by those works.

Luther's soteriology, in the Freedom of a Christian Man at any rate, does confirm another claim by shuger, that the God of evangelical theologians considers not acts but persons. But the confirmation comes only to underline how Shuger under-reads the seriousness of the Lutheran position. For Luther, God's pre-judgment of humans does pre-exist acts, not least because those acts are already and always irredeemably inadequate. They spring from the utterly fallen persona whose corruption produces the inadequate acts. The Lutheran drama is much more fierce 
than can be accommodated in sentimental talk of God's kindly and equitable treatment of people, not tats.

So far, though, we have been citing Luther. If the territory of dispute is English materials, let us turn to Tyndale. What of the English reception of Lutheran soteriology? Was it unreasonable of More in 1532 to express shock at the evangelical soteriology available to him in England by that date? ${ }^{53}$

The Prologue to Tyndale's 1525 New Testament is a cardinal document, standing as it does as the very first welcome to the printed vernacular scriptures in English. A short introductory section is a translation of the Preface to Luther's 1522 New Testament, with the rest, apparently, Tyndale's own work. ${ }^{54}$ The short section drawn from Luther offers, as we might expect, a warm welcome. "Evangelion," we are told, is a Greek word meaning "good merry, glad and joyful tidings, that maketh a man's heart glad, and maketh him sing, dance, and leap for joy" (9). This good news is, however, soon subject to less uplifting intelligence about the self anterior to acts. In the section for which no Lutheran source has been located, Tyndale expatiates on Luther's valuation of human worth, and here the news is very bad indeed. By Adam's fall we are "children of wrath and heirs of the vengeance of God by birth." We have 
our fellowship with the damned devils...while we are yet in our mother's wombs; and though we show not forth the fruits of sin [as soon as we are born], yet are we full of the natural poison, whereof all sinful deeds spring, and cannot but sin outwards (be we never so young) [as soon as we are able to work] if occasion be given." (14)

Of course this (and there is a good deal more of it) is part of the Lutheran emotional dialectic: one must, in faith, recognize one's utter abjection before God, by way of activating God's grace. "By grace...we are plucked out of Adam, the ground of all evil, and graffed in Christ, the root of all goodness" (14). Tyndale makes the emotional pattern clear: the situation is not unlike the sentenced criminal who sees nothing before him but "present death," at which point a charter from the king arrives to deliver him (16):

Likewise, when God's law hath brought the sinner into knowledge of himself, and hath confounded his conscience and opened unto him the wrath and vengeance of God; then cometh good tidings. The Evangelion sheweth unto him the promises of God in Christ, and how that Christ hath purchased pardon for him, hath 
satisfied the law for him, and hath appeased the wrath of God. (17)

Tyndale articulates, then, standard Lutheran theology of salvation: out of a faithful self-loathing, and accurate estimation of total incapacity, arises an overwhelming sense of gratitude to a God who takes all initiative into his own hands and works all by grace. The text of Scripture here is no mere bearer of the story, since, as with the letter borne to the criminal awaiting execution, it plays a crucial part in the story. From this welcome to scripture we learn not only that we will appreciate our abjection only by reading scripture; we also learn that the same scripture will bring the necessary letter of release. Reading is an indispensable element in this soteriology, a bringer of good news that will not arrive if scripture is not also read as bad news.

Tyndale is not prepared to leave the "welcome" there, however, and goes on to summarize and develop all that's been said. Our will "is locked and knit faster unto the will of the devil, than could an hundred thousand chains bind a man unto a post" (17). This submission to the devil is itself a textual phenomenon, as "the law and will of the devil is written as well in our hearts as in our members, 
and we run headlong after the devil with full zeal, and the whole swing of all the power we have" (17).

The textual experience, with the devil's text written onto our hearts, is the full blown Lutheran experience of what I have elsewhere called "textual hatred."56 It is impossible for a natural man to consent to the law or to believe that the God who made the law is just. Such a law "only setteth man at variance with God,"

And provoketh him to and stirreth him to rail on God, and to blaspheme him as a cruel tyrant. For it is not possible for a man, till he be born again, to think that God is righteous to make him of so poison a nature...and to give him a law that is impossible for him to do, or to consent to; his wit, reason and will being so fast glued, yea, and chained unto the will of the devil. (18, a passage added to the 1530 version) This is obviously (to my mind) a fierce soteriology, focused relentlessly on a self anterior to acts, wholly because that self is so corrupt as to produce only fallen acts. The kindly father, whose justice operates in the manner of the law of equity, is wholly unrelated to operations of this utterly serious, fearsome deus absconditus. 
Shuger is right to insist that I lay great store by the differing account of works in pre- and post-Reformation theologies. She is also right to say that Luther focuses on the self anterior to acts. Her incredulity at Reformation revisionism arises, however, from her under-reading of that always already irredeemably guilty self, and the ferocity of its judge.

Despite my claim to step back from the heat of controversy, I have instead engaged in hand to hand combat in this essay. A defense needs to defend, it's true. That said, I end by referring to the title of the present essay, "The Reformation of Scholarship." I also end by frankly confessing that the kind of debate conducted by Shuger and me looks decidedly passé, by about a decade, now that Trans-Reformation Studies has progressed so far and so fast. English literary studies have indeed moved beyond the five-hundred year agon of mirroring Reformation polemical distortion, in the astonishing productivity of the last ten years referred to above. ${ }^{57}$ Historians have for a long time regarded the Reformation as part of a sequence of reforming moments, and routinely consider the "long Reformation," even in basic text books. ${ }^{58}$ Literary historians are increasingly aware of the many models of relationship 
between pre- and post-Reformation cultures in England. ${ }^{59}$ One of those models, relevant to the debate between shuger and me, can be described as a relation of continuity, "even if that continuity might be visible only after the event, when pre-Reformation materials begin to look prophetic of the convulsions to come." 60 Rather than positing stark periodic contrasts, that is, scholarship might look to the "prophetic" moments before the most obvious markers of change. Luther, for example, may have utterly dismissed the late medieval distinction between God's absolute and ordained power. The very impulse to make that distinction in the first place, however, arises from the acute late medieval sense of God's absolute power that also produced Lutheranism. ${ }^{61}$ In English literary studies, neither "Early Modern" nor "Medieval studies" are any longer comfortably containable periodic designators. I therefore hope that scholars like Shuger (for whom my admiration is in no way feigned) and Simpson can stop wrestling and start engaging in the truly transformative work of making history whole.

1 Debora Shuger, "The Reformation of Penance," Huntington Library Quarterly 71 (2008): 557-71. 
2 For an extraordinary conspectus of the main traditions of this scholarship, see A. G. Dickens and John Tonkin, The Reformation in Historical Thought (Cambridge, MA: Harvard University Press, 1985). For bibliographical guidance into the larger field of Reformation studies, I am deeply indebted to Alexandra Walsham, "Migrations of the Holy: Religious Change in Medieval and Early Modern Europe," forthcoming

3 Some decisive, initiating works of which historical tradition are The English Reformation Revised, ed. Christopher Haigh (Cambridge: Cambridge University Press, 1987), and Eamon Duffy, The Stripping of the Altars: Traditional Religion in England, 1400-1580 (New Haven: Yale University Press, 1992) .

4 The seminal articles for the periodic challenge in English literary history are David Aers, "A Whisper in the Ear of the Early Modernists, or Reflections on Literary Critics Writing the "History of the Subject", in Culture and History 1350-1600. Essays on English Communities, Identities and Writing, ed. David Aers (London: Harvester Wheatsheaf, 1992), 177-202, and Lee Patterson, "On the Margin: Postmodernism, Ironic History, and Medieval Studies," Speculum, 65 (1990): 87- 
108. A good deal more scholarship designed to redraw the periodic boundaries, and to reflect on the premises of periodization, followed in the early 2000s. See, for example, James Simpson, Reform and Cultural Revolution, 1350-1547, volume 2 of The Oxford English Literary History (Oxford: Oxford University Press, 2002), and the volume of essays devoted to that book, in JMEMS 35 (2005). Since then a quickly growing body of scholarship has examined the periodic boundary either so as to dissolve it or to conceive it afresh. See, for example, Reading the Medieval in Early Modern England, ed. David Matthews and Gordon McMullan (Cambridge: Cambridge University Press, 2007), and the books so far published in The University of Notre Dame Press's series "ReFormations, Medieval and Early Modern," (i.e. Robert Barrett, Against all England: Regional Identity and Cheshire Writing 1195-1656 (Notre Dame: University of Notre Dame Press, 2009); Patricia Badir, The Maudlin Impression: English Literary Images of Mary Magdalene, 1550-1700_(Notre Dame: University of Notre Dame Press, 2009); and Nancy Bradley Warren, The Embodied Word:

Female Spiritualities, Contested Orthodoxies, and English Religious Cultures, 1350-1700 (Notre Dame: 
University of Notre Dame Press, 2010)). Most recently, and with widest range, see the 32 essays in Cultural Reformations: Medieval and Renaissance in Literary History, ed. Brian Cummings and James Simpson, TwentyFirst Century Approaches, 2 (Oxford: Oxford University Press, 2010).

5 Indeed, one of the especially significant literary historians who first challenged the disabling periodic strictures of literary history was also one of the first to offer a penetrating critique of Duffy's Stripping of the Altars; see David Aers, "Altars of Power: Reflections on Eamon Duffy's The Stripping of the Altars," Literature and History, third series, 3 (1994): 90-105. 6 Simpson, Reform and Cultural Revolution; Shuger directs her attention at Chapter 7 .

7 William Allen, A defense and declaration of the Catholike Churchies [sic] doctrine, touching purgatory, and prayers for the soules departed (Antwerp, 1565), STC 371.

8 Shuger, "The Reformation of Penance," 559.

9 Shuger, "The Reformation of Penance," 559.

10 Allen's biography is conveniently available online in the Oxford Dictionary of National Biography, from which this citation and my potted biography is derived. 
11 William Allen, A True, Sincere and Modest Defence of English Catholics that Suffer for their Faith, ed. Robert M. Kingdon (Ithaca: Cornell University Press, 1965). Allen's text was published in 1584.

12 Shuger, "The Reformation of Penance," 559.

13 See, for example, Thomas More's Supplication of Souls of 1528 and Simon Fish's Supplicacyon for the Beggers of 1528, both edited in Thomas More, Letter to Bugenhagen; Supplication of Souls, Letter against Frith, ed. Frank Manley, Germain Marc'hadour, Richard Marius and Clarence H. Miller, The Yale Edition of the Complete Works of St. Thomas More, 7 (New Haven: Yale University Press, 1990). The attack is of course older: see Anne Hudson, The Premature Reformation: Wycliffite Texts and Lollard History (Oxford: Clarendon Press, 1988), 309-10. Hudson points to questioning of the existence of purgatory as early as 1416 (309) .
14 Allen, $A$ defense and declaration of the Catholike Churchies [sic] doctrine, touching purgatory (Antwerp, 1565), STC 371, cited from EEBO, image 55, page 54v. All spelling here and elsewhere in this essay has been modernized. All future references to this text will be made to this digital facsimile edition, cited by image number. 
15 See, for example, Allen, A defense and declaration of the Catholike Churchies [sic] doctrine, touching purgatory, image 33 for Melanchthon, and image 38 for Calvin. 16 For this argument in English historiography, see Thomas Betteridge, "Vernacular Theology," in Cultural Reformations, ed. Cummings and Simpson, 188-205 (at 190), and further references. For the history of confessionalization in Germany, see Heinz Schilling, "Confessionalisation in the Empire: Religious and Societal Change in Germany between 1555 and 1620," in his Religion, Political Culture and the Emergence of Early Modern Society: Essays in German and Dutch History (Leiden: Brill, 1992), 205-45; for a European conspectus, see Heinz Schilling, "Confessionalisation and the Rise of Religious and Cultural Frontiers in Early Modern Europe," in Frontiers of Faith: Religious Exchange and the Constitution of Religious Identities 1400-1750, ed. Eszter Andor and István György Tóth (Budapest: Central European University, 2001), 21-35. I am indebted to Alexandra Walsham, "Migrations of the Holy," note 42, for these references. 17 Shuger, "The Reformation of Penance," note 5. 18 For convenient summary of this regime, which operated from the seventh to the twelfth century, and itself 
replacing an even earlier one, see Thomas N. Tentler, Sin and Confession on the Eve of the Reformation (Princeton, NJ: Princeton University Press, 1977), 9-15. 19 Shuger, "The Reformation of Penance," 560. 20 For which see the lucid study by Edward Peters, Torture, expanded edition (Philadelphia, 1985), Chapter 2. 21 For a lucid summary of the broader topic of justification in the Tridentine and post Tridentine Church, see Alister E. McGrath, Iustitia Dei: A History of the Christian Doctrine of Justification, third edition (Cambridge: Cambridge University Press, 2005, first published 1986), Chapter 4 .

22 For the second regime, see Tentler, Sin and Confession on the Eve of the Reformation, Chapters 2-6. 23 Shuger, 558: "[Simpson's] discussion centers on two such ostensible shifts."

24 Simpson, Reform and Cultural Revolution, 363: "the dette that remains even after absolution." Shuger (569) points out that restitution is a precondition of absolution, and that I should be referring to restitution, not satisfaction.

25 I say "possibly just" correction since this is clearly a matter of dispute. According to Tentler, the main late 
medieval tradition has it that the intent to do

satisfaction precedes absolution (Tentler, Sin and

Confession on the Eve of the Reformation, 283).

26 Shuger, "The Reformation of Penance," 561

27 Shuger, "The Reformation of Penance," 562

28 Shuger, "The Reformation of Penance," 563.

29 Shuger, "The Reformation of Penance," 564.

30 Shuger, "The Reformation of Penance," 564. The citation

is from Tyndale, An Answere unto Sir Thomas More's

Dialogue.

31 Shuger "The Reformation of Penance," 566.

32 Shuger, "The Reformation of Penance," 561.

33 For Luther's theology in its historical perspective, see McGrath, Iustitia Dei: A History of the Christian Doctrine of Justification, Chapter 3. For Luther's dismissal of works as a way of remitting the debt of sin, see, for example, Martin Luther, The Freedom of a Christian, in Luther's Works, 31, Career of the Reformer, 1, ed. Harold Grimm (Philadelphia: Muhlenberg Press, 1957), 327-377. For Luther's denial of free will, see, for example, Martin Luther, On the Bondage of the Will, in Luther and Erasmus: Free Will and Salvation, trans. E. Gordon Rupp, A. N. Marlow, Philip S. Watson and B. Drewery (Philadelphia: The 
Westminster Press, 1969). For Luther's predestinarianism, see, for example, his Preface to Romans, in Luther, "Preface to the Epistle of Paul to the Romans," in Martin Luther, Prefaces to the New Testament, in Luther's Works 35, Word and Sacrament 1, ed. E. Theodore Bachmann (Philadelphia: Muhlenberg Press, 1960), 378. See also Gordon Rupp, The Righteousness of God: Luther Studies (London: Hodder and Stoughton, 1953), 186-191. 34 For a detailed history of these concepts, see McGrath, Iustitia Dei: A History of the Christian Doctrine of Justification. For a recent and especially subtle account of the late medieval sacrament of penance, see Sarah Beckwith, Shakespeare and the Grammar of Forgiveness (Ithaca and London: Cornell University Press, 2011), Part 1, pp. 15-56. See page 36 for Aquinas' specific repudiation of vindictive justice as a fit description of the sacrament of penance.

35 Thomas More, The Confutation of Tyndale's Answer, ed. Louis A. Schuster, Richard Marius, James P. Lusardi, and Richard J. Schoeck, The Complete Works of St Thomas More, 8, 3 Parts (New Haven: Yale University Press, 1973).

36 Thomas More, A Dialogue Concerning Heresies, ed. T. M. C. Lawler, Germain Marc'hadour and Richard Marius, 2 Parts, 
in The Complete Works of St Thomas More, 6 (New Haven: Yale University Press, 1981) .

37 More, The Confutation of Tyndale's Answer, ed. Schuster, Marius, Lusardi, and Schoeck, 8: 884.

38 More, The Confutation of Tyndale's Answer, ed. Schuster, $8: 885$

39 More, The Confutation of Tyndale's Answer, ed. Schuster, $8: 886$

40 For which, see James Simpson, Burning to Read: English Fundamentalism and its Reformation Opponents (Cambridge, MA: The Belknap Press of Harvard University Press, 2007), Chapter 7 .

41 More, The Confutation of Tyndale's Answer, ed. Schuster, $8: 888$

42 More, The Confutation of Tyndale's Answer, ed. Schuster, $8: 897$.

43 More, The Confutation of Tyndale's Answer, ed. Schuster, $8: 898$

44 More, The Confutation of Tyndale's Answer, ed. Schuster, $8: 898$

45 The following five paragraphs are drawn from Simpson, Burning to Read, Chapter 3 . 
46 Martin Luther, The Freedom of a Christian, in Luther's Works, 31, Career of the Reformer, 1, ed. Harold Grimm (Philadelphia: Muhlenberg Press, 1957), 327-377 (at 346$47)$.

47 For the profile of despair in English puritan culture more generally, see John Stachniewski, The Persecutory Imagination: English Puritanism and the Literature of Religious Despair (Oxford: Oxford University Press, 1991). 48 For the medieval tradition of applied, ethical readings, see Winthrop Wetherbee, "The Study of Classical Authors: From Late Antiquity to the Twelfth Century," and Vincent Gillespie, "The Study of Classical Authors: from the Twelfth Century to c. 1450," both in The Cambridge History of Literary Criticism, volume 2, The Middle Ages, ed. Alastair Minnis and Ian Johnson (Cambridge: Cambridge University Press, 2005), 99-144 and 145-238. 49 See Martin Luther, On the Bondage of the Will, in Luther and Erasmus: Free Will and Salvation, trans. E. Gordon Rupp, A. N. Marlow, Philip S. Watson and B. Drewery (Philadelphia: The Westminster Press, 1969).

50 Luther, The Freedom of a Christian, ed. Grimm, 348.

51 Shuger, "The Reformation of Penance," 561. 
52 For the question of Tyndale's agreement or disagreement with Luther regarding works, see William A. Clebsch, England's Earliest Protestants, 1520-1535 (New Haven: Yale University Press, 1964), and Carl Trueman, Luther's Legacy: Salvation and English Reformers, 1525-1556 (Oxford: Clarendon Press, 1994). Both Clebsch and Trueman argue that Tyndale adopted a covenant doctrine concerning the Christian's relationship with God. Such a doctrine is at odds with Luther's repudiation of any pact whatsoever, since a pact would constrain God's wholly unbounded prerogative. Clebsch argues that the repudiation of Luther is complete by 1530, by which time Tyndale had rejected God's opus alienum and instead domesticated the law (155). It is true that, in the 1534 New Testament prologue, Tyndale does stress the importance of works within a "general covenant" (4). The prologue as a whole, however, offers no resolution between that non-Lutheran accent and the distinctively Lutheran statements made elsewhere in the same Prologue.

53 The following three paragraphs are drawn from Simpson, Burning to Read, Chapter 3 .

54 The English text is available as The Pathway into the Holy Scripture, in William Tyndale, Doctrinal Treatises and 
Introductions to Different Portions of the Holy Scriptures,

ed. Henry Walter (Cambridge: Cambridge University Press, 1848), 7-28. The Pathway is a revision of the 1525

Prologue. All further references to this text in this essay will be made by page number in the body of the text. An English translation of Luther's prologue to his 1522 New Testament is available in Martin Luther, Prefaces to the New Testament, in Luther's Works 35, Word and Sacrament 1, ed. E. Theodore Bachmann (Philadelphia: Muhlenberg Press, $1960), 357-62$.

55 The passages in square brackets did not appear in the 1525 Prologue, and were added to the 1530 edition of the Pathway.

56 See Simpson, Burning to Read, Chapter 3. 57 James Simpson, "Diachronic History and the Shortcomings of Medieval Studies," in Reading the Medieval in Early Modern England, ed. David Matthews and Gordon McMullan (Cambridge: Cambridge University Press, 2007), 17-30, reflects on the transformative moment and offers a brief history of the debate within English literary studies.

58 See, for example, James D. Tracy, Europe's Reformations, 1450-1650: Doctrine, Politics and Community, second edition 
(Lanham: Rowman and Littlefield, 2006), and Peter G.

Wallace, The Long European Reformation: Religion, Political

Conflict, and the search for Conformity, 1350-1750

(Basingstoke: Palgrave, 2004). For a cultural-philosophical

history that sees the sixteenth-century Reformation as part

of a much longer sequence of disciplinary movements, see

Charles Taylor, A Secular Age (Cambridge, MA: Belknap

Press, 2007), Chapter 2 .

59 For articulation of which, see Cummings and Simpson,

"Introduction," in Cultural Reformations, ed. Cummings and Simpson, 5-7.

60 Cummings and Simpson, "Introduction," in Cultural

Reformations, ed. Cummings and Simpson, 6 .

61 See Heiko Oberman, The Harvest of Medieval Theology:

Gabriel Biel and Late Medieval Nominalism, revised edition

(Grand Rapids, MI., 2000; first published 1963). For a

broader but wonderfully succinct account of the late

medieval forerunners of Lutheranism, see Quentin Skinner,

The Foundations of Modern Political Thought, 2 volumes

(Cambridge: Cambridge University Press, 1978), Volume 2,

Chapter 2. For a more recent review of the relations

between late medieval Augustinianism and Reformation

theology, see McGrath, Iustitia Dei: A History of the 
Christian Doctrine of Justification, Chapter 3. For more specific studies of later medieval forerunners of Reformation evangelical positions, see, for example, Gordon Leff, Bradwardine and the Pelagians: A Study of his "De Causa Dei" and its Opponents (Cambridge: Cambridge University Press, 1957), and David Aers, Salvation and Sin: Augustine, Langland, and Fourteenth-Century Theology (Notre Dame, Indiana: University of Notre Dame Press, 2009), Chapter 3 . 